\title{
The Construction of Full Citizenship in a Vision of the Brazilian Digital Inclusion in Education
}

\author{
Francisco Roberto Ferreira dos Santos \\ Universidade Catolica de Brasilia \\ robertosantoz@gmail.com \\ Ildefonso Rodrigues Teixeira \\ Universidade Catolica de Brasilia \\ ildefonso.teixeira@ outlook.com
}

\begin{abstract}
This article discusses the importance of digital inclusion in the construction of citizenship. The central point when discussing social inequality is citizenship with impacts on the structure transformation present in society. The opportunities created by digital inclusion can transform the conditions of the individual, leading to the construction of citizenship from greater participation in political life and in public decisions. Digital inclusion can promote the participation of the individual in cyberspace which becomes the sphere for public debates and a space for State decisions. The critical use of techniques and information technology along with other actions which promotes equality can lead to the development of full citizenship and requires a new transformation in the meanings of work, responsible for occupation and social inclusion. Considering the adjustments for digital inclusion, social programs can go "beyond mere access" to computers and internet and changes and in the social space.
\end{abstract}

Keywords: Inclusion, Digital inclusion, Citizenship, Information literacy, Social inequality; Education.

\section{Introduction}

The so called Society of Information, in the present $21^{\text {st }}$ century, has presented many social problems that are related to the lack of full citizenship, such as marginalization of the individual and poverty. Nevertheless, social programs of digital inclusion are practiced as a possible way of access to information and communication technologies, which are crucial for the promotion of political, civil and social rights.

With that aim, there are currently in Brazil, ninety-nine digital inclusion programs registered in the database of the National Monitoring Centre of Digital Inclusion, where approximately 5,700 telecenters are mapped. Amongst those programs, 74 are executed in Public Management and 25 in Civil Society. They reach every public sphere, being 36 present in municipal, 10 in regional, 24 in state and 29 in national areas.

In this manner, social programs of digital inclusion are used by the parcel of community thatseeks a way of improving its life standard through acquiring technical abilities that the labor market demands. However, those social programs are not fully developed to transform 
Brazilian social reality, critically promoting the access of the individual to pertinent information to its belonging and participation in social space.

On the other hand, there are dialectics present in such spaces which aim the digital inclusion once they promote the formation of the working force necessary to the operational labor market. But, at the same time, they also create a socialization space of life experience and knowledge; capable of developing a critical awareness of the life conditions those individuals are inserted in. This way, the social programs of digital inclusion become important socialization and citizenship construction spaces, even if parallel to this process is also the technical education practice that serves the labor market interests. Nevertheless, such programs require improvements in order to reach the complete development of those individuals, promoting the digital inclusion (access to technology and information) and a full citizenship construction.

It is of extreme importance understanding the citizenship construction process and its relation to social programs of digital inclusion practiced in Brazil in order to reduce the social problems related to marginalization and poverty.

\section{Full Citizenship}

In the western world, the word citizenship has an antique origin. It takes us back to old Greeks. For them, citizenship was the condition of all of those who had the right to participate in the political life of the city. It is also considered a historical human creation that has always been marked by its political construction character and by the nature of the society where it is inserted, and that since the old Greeks and Romans time.

Nowadays, citizenship is discussed at length in Brazil. It is often possible to see the word as part of municipal and state governments' slogans, at the same time authorities, politicians, political parties and non-governmental organizations use it frequently in their speeches. In many cases, the way this word is used only takes away its essential use. Just an example of it is the use of the term by certain government authorities as a slogan of their administration, which is nothing beyond mere political opportunism: a trend-word - and that, in a country where many basic rights are not yet guaranteed - that has been transformed into the synonym of 'gift' by those authorities in their relation with the population. In other words, something that has to be provided by the State and every citizen's right, has been transformed into "kindness" and "charity" by the politicians.

For such a use of the word - and the practices extended to it - citizenship is no longer treated as a political-social condition which is the right of every citizen or as a political conquest and a collective construction. On the opposite, it has been presented as a concession, a present, and a bonus, given by those who have political powers; as a virtuality, always precarious, as if it depended on the power's will, and not as something that should be or already is ensured by Law.

Connected to the emptying of the word is also the fact that citizenship has been considered as being only the access to basic rights - to food, home, health, education and transportation - 
complemented by certain civil and political rights. In general, in Brazil, organizations, political parties, politicians and populist governors on their populist rhetoric dispute over those basic - at the same time obvious - rights.

But other less obvious rights have been left out of the concept of citizenship broadly proposed and accepted, endangering the construction of a full citizenship in Brazil. What is actually missing in the current idea of citizenship?

The same old story; a story that repeats itself - we shall return to the ancient Greeks. In ancient Greece, due to their valid social structure and moral convention, women, foreigners and slaves were prohibited of taking part in the political life of the city. In other words: even having invented the idea of citizenship and democracy of the Western world, ancient Greeks excluded broad parts of the society from citizenship. Nowadays, in many societies, the story is the same.

In Brazil, broad sectors of society continue to be excluded from citizenship because of social structures and mere moral conventions. Women - despite their conquests -, as well as homosexual, Afro-American, indigenous, handicapped and poor people continue to suffer prejudice and exclusion from citizenship. And amongst those, some suffer a higher degree of exclusion than another, based on prejudices that justify unacceptable exclusions.

Emptied of its essential meaning by opportunist political appropriation that transform it in mere rhetoric, or transformed in synonym of another basic right - or yet, in a right valid for some and not for others -, citizenship is now confiscated and reduced. Because of that, it is no longer authentic citizenship: the full privilege, without distinction of any nature, of the rights regarding life, liberty and happiness for each and every one and not just access to obvious basic rights. This is the idea that must be established for the concept and practice of full citizenship, without concession to prejudices that transform individuals previously referred as non-citizens or half-citizens. Citizenship and democracy cannot be privileges of only a part of society - the same society that, for economic reasons or mere cultural or moral conventions, take advantage of an exclusive right.

\section{Digital inclusion and full citizenship: a necessary rapport}

For a better understanding of the relation between digital inclusion and citizenship, I will start this section with a theoretical discussion. Scholars such as José Murilo de Carvalho, T.H. Marshall, Wanderley Guilherme dos Santos and so many others have contributed to this analysis. Thereafter, I will explore the concept of digital discussion from the point of view of researches such as as Maria Lúcia Becker and others.

Marshall (1967) introduces the citizenship construction in England between the $18^{\text {th }}$ and $19^{\text {th }}$ centuries as part of the "social equality problem", where everyone should be equally treated independently of their classification/place in society. Social education was responsible for the transformation of society's point of view, causing an impact on the way people took part in the political life. Therefore, the citizen's level of education turned out to be a primordial 
factor for citizenship makes itself present in the history of a nation, once education is also a social right of citizenship.

The central point when it comes to social inequality is citizenship, with transforming impact over the society's structure in vigor. Such proposal can be observed in Marshall (1967) who suggests citizenship as being the equality of rights and obligations, and the "social class, on the other hand, a system of inequality" (p. 76), strengthened by ideas, values and beliefs. In this manner, at the same time that citizenship was constructing an equality of rights, it was still not establishing the equality of social rights, which left open spaces for a competitive market economy to set in, defending what the individual's right within economic competition. The capitalist competition was growing and used all the strategies available for it, expanding in all directions and basing itself on class inequality - for the rich to exist, the poor would have to be exploited.

The prejudices of class were consequence of a poor distribution of income and an unequal economic struggle within the capitalist system of production. And that despite of the concept of citizenship be already present in society, though, under construction. Marshall (1967) mentions that in spite of so much struggle in England during the mid- $19^{\text {th }}$ century, what could have seen was the strengthen of the market economy and the contractual system to the detriment of social right. However, the progress made by society through education and the change of thought, have contributed to the fight for a more equal society. Such changes have led to social right, which acquired a new sense, restructuring not only the life of the poor, but also of the rich. That causes a reduction on the distance separating them, and not on their income:

What matters is the general enrichment of the concrete substance of civilized life, a general reduction of risk and insecurity, a leveling between the most and least favored in every aspect - between the healthy and sick, the employed and the unemployed, the elderly and the active, the single and the head of a large household. The leveling does not refer as much to class as it refers to individuals that are part of a population that is considered, for such intent, as it were a class. The equality of status is more important than the equality of income. (Marshall, 1967, pp. 94-95)

Thus, education and occupation can promote certain social status differences, that depend on the education and occupation achieved and are rewarded in society. In this manner, the existence of relevant differences in relation to social status imposes inequality among social classes and therefore, the conflict of class. Nevertheless, capitalism presupposes social classes, but what it can be visualized in the construction of citizenship within the broad capitalist production system is the attempt of reducing differences and making them "irrelevant in face of the social status".

The education matter is called into question as a factor of great importance, even with different notions, for citizenship to be built and its maintenance performed by everyone in an equal way. Marshall (1967) presented relevant points for the understanding of citizenship that 
we also seek to comprehend with Wanderley Guilherme dos Santos, orientating the analysis to the social context of Brazil.

Santos (1979) suggests that "the history of governmental interference in social relations regulation in Brazil is not so different from the standard experience revealed by other countries" (p.15), once the capitalist ideology was transforming the social relations in contracts. However, there is a distinction between Brazil and other countries. Such distinction can be perceived in the Estate action and how it is executed with the Brazilian society scope, with its own political and social characteristics.

On the other hand, the first Brazilian constitution of 1824 does not describe relevant actions towards society when it comes to the proposal of social problem reduction of the time. The same slaveholding Brazil of 1824 did not regulate professions and maintained its position in the republican constitution of 1891 in the defense of particular interests, protecting certain privileges and identities in the society's body, and violating the rights of many even as it was constructing civil rights in Brazilian citizenship. Besides, before the citizens' rights were recognized via social security legislation independently of its occupational position, Brazilian citizens had to wait until the constitution of 1934, which at the same time recognized the social obligation of the State and its right of regulating the exercise of professions (Santos, 1979, p. 20).

In this manner, what can be perceived is the government's pretension of regulating more than just the professions, but also the social status construction and consequently, Brazilian citizenship. Brazilian citizenship is regulated by the State in such a way that the latter could be able to control syndical movements, serving the interests of those who were in fact, represented by the State. Syndicates were subservient to the industrial elite interests, instead of fighting for the promotion of labor rights, social protection and Brazilian citizenship construction. The practice of strikebreaking characterized the syndical bureaucratizing and the regulation of actions practiced in syndicates by the State.

The history of Brazil presents political actions in the 1950s that mine and weaken the population desire of answering to the workers fights for proper work conditions, or corresponding to the rights and duties described in civil, political and social law. In spite of the long way Brazilian people have gone through towards full citizenship, what can actually be seen is that, such journey was poorly recognized by politicians until the 1960s.

Nevertheless, Brazilian social politics shows important changes after 1975, although the country is under the authoritarian government of Military Dictatorship at the time and would be in vigor from 1964 to 1985 . The problem hereby expressed is on the social inequality presence in practically every community once a capitalist system of production is practiced, along with ideologies that defend the competitive market. Reinforcing the idea once again, the intention is to reduce inequality, because extinguishing it completely would be impossible. But, in Brazil, citizenship construction with the intention of reducing social inequality suffered impacts from certain interests of regulatory policy practiced by the "social-economic politics after the 1930s", based on regulated citizenship and presented by Wanderley de Souza Santos: 
By regulated citizenship, it can be understood the concept of citizenship whose roots can be found not in political values codes, but in a system of occupational stratification that has been defined by a legal norm. In other words, citizens are all those who are members of community and has an occupation recognized by law." (Santos, 1979, p. 75).

It is the State that regulates professions and therefore, defines citizenship as the right of having an occupation offered by the labor market to the detriment of the social field, due to the condition in which the individual is inserted. Thus, Wanderley Guilherme dos Santos (1979) presents the "points of contact and the points of difference" of Brazilian social policy along with other international policies such as the English, described by T. H Marshall (1967). On the other hand, Murilo de Caravalho (2003) does instigate reflections on Brazilian citizenship construction, inverting the order of the rights Marshall has put in evidence.

The new process of democratization Brazil experienced after military dictatorship in 1985 led to the adoption of the word citizenship in an unmeasured way, which caused the loss of the real value of citizen status. Social problems related to urban violence, unemployment, illiteracy amongst other, have led society to not recognize citizens of a State what comes to their good standing of social, civil and political rights. "The full citizen would be that one who were holder[s?] of the three rights," argues Carvalho (2003, p. 9).

In Brazil, the vote as a political right has been used to promote some groups and has not ensured other rights such as education, health, employment and others that are extremely important to validate the citizenship status. The construction of citizenship demands a long path to be gone through and in a cautious way, to avoid the mistake of transforming it in anything else that is not the quality of full citizen. Therefore, education is defended by Carvalho (2003), as Marshall and Santos have done, once it is the first right to be ensured in order to make all the others present:

In countries where citizenship has developed in a faster way, including England, for a specific reason popular education was introduced. It was it that has enabled people to be aware of their rights and organize themselves to fight for them. The absence of an educated population has always been one of the main obstacles for the construction of a civil and political society. (Carvalho, 2003, p. 11).

Education it is then crucial for a society to construct and respect itself, based on the rights and duties of citizens. The historical nature of the term citizenship refers to the Nation-state, in French Revolution in 1789 that T. H. Marshall discusses on his work Citizenship, Social Class and Status. The relation of the citizen status with its sense of belonging strengthens citizenship.

On the other hand, based on technique and technology capitalism develops itself, shortening the power of the State with the deterritorialization and loss of identity with the place of belonging. Seeking answers for the problems regarding the construction of Brazilian citizenship, José Murilo de Carvalho (2003) describes the historical processes Brazil State has gone through in order to became a nation. 
A history outlook presents Brazil from 1822 to 1930, with the independence proclamation (1822), slavery abolition (1888), republic proclamation (1889) and the coup d'état (1930), all of them were much more formality than reality and with little social-political change for Brazil. The relation between an independent nation and at the same time proslavery mined the conditions for the existence of full citizens - even coffee barons lacked the sense of citizenship.

Education, defended by Carvalho (2003, p. 24) as "the first right to be practiced, was not considered as part of Brazil's development after the independence in 1822". The civil rights benefited a few people, political rights even fewer people and, the social rights were not discussed because the social service was the left to church and private parties to take care of. After all, the masters were not interested in educating their dependents or slaves, as well as the Portuguese administration in educating the non-Portuguese. People regarded as citizens were those who had the same financial conditions of rich farms, so the majority did not have the necessary conditions to "receive" the status of citizen. Such actions have weakened the construction of Brazilian citizenship.

Brazil's history, despite so many registered facts, does not present important transformations for its population, but only superficial changes of order maintenance - this means the elite in power. Maintenance of the political order in power becomes each day more decisive in the non-investment on primary education for population, once education would make the questioning of order possible by the excluded of society. Belonging to a social space could, then, emerge through the inclusion of many in work spaces, providing favorable conditions for workers to have access to education and become more active in the city.

Such notion of belonging is valuable according to Carvalho (2003), once the combination of forces among the working class would be extremely important for them to fight for their civil and social rights. In this manner, in spite of the the lack of investment in social spaces capable of transforming the people, it can be perceived its struggle to conquest its citizen space - there are dialectics present on that. Popular participation makes the sense of citizenship grow, but not in the way it should be - full. Some rights are considered and others are forgotten by society that is more worried about the economic development.

Brazil, from 1930 to 1964 experienced historical facts that guaranteed citizenship to a certain extent. The Vargas Era (1937), the Consolidation of Labor Laws (1943), the constitution of 1946 amongst other, as the syndicate reforms. Nevertheless, what reinforced the construction of citizenship were the base reforms that somewhat came from popular manifestations for full rights, despite of the pressure made by the elite and militaries to maintain the order against equality of rights. "Political mobilization was made around what it became known as 'base reforms', a generic term to indicate land, fiscal, banking and educational reforms" (Carvalho, 2003, p. 140).

Every movement made for citizenship construction and development of the space for citizens has been ignored by Brazilian elite and middle-class, concerned with their particular interests and not with what was good for the nation. Thus, the Military Dictatorship era represented a "step back" for the construction of Brazilian democracy. From 1964 to 1985, Brazil suffered 
with institutional acts that destroyed previous achievements of the people related to the citizen space in society. However, in 1988, the new democracy presented what became known as the Citizen Constitution by its liberal and democratic character.

The lack of civil rights ensuring and the velocity in which the country has been urbanized, led to an increase in urban violence that still affects full citizenship. Additionally, Brazilian logic in relation to the rights has been inverted if compared to the English logic demonstrated by $\mathrm{T}$. H. Marshall, according to Carvalho (2003). Finally, population claims today, for the right of consuming to the detriment of citizenship. The exercise of full citizenship in a "war" against capitalism according to Marshall (1967) and at the same time confuse according to Carvalho (2003), therefore still without a plausible solution, demanding practices that increase the citizens' rights and are able to reduce social inequalities in Brazil.

\section{Digital inclusion: possibilities and challenges for the construction of citizenship}

Maria Lúcia Becker (2009), in her work on Digital inclusion and citizenship; the possibilities and illusions of technology solutions, reinforces the idea of inequality reduction within the capitalism way of production through digital inclusion, which can balance the inequality of citizenship status creating opportunities of access to services and rights.

Digital inclusion would then compensate the inequality of citizenship status with 'the equality of opportunities' of information, qualification for a better positioning in labor market, access to knowledge enabling the action for the defense of own rights, communication and expression. (Becker, 2009, p. 14)

Thus, the discussion on digital inclusion is necessary with the many spaces of debate as a possibility of exercising citizenship, reducing inequality as a way of managing the social problem until structural transformation of capitalist production is conquered, resulting in a full citizenship. And there is also the necessity of solving the problem of the distinguished access to computer networks by everyone, providing access to other rights such as education, employment and health.

The opportunities created by digital inclusion can transform individuals' conditions, enabling their contribution to citizenship construction through a greater participation in political life and public decisions without adhering to the digital inclusion speech. Becker (2009) mentions that in many research reports made on digital inclusion and citizenship, the most frequent matter was the necessity of a life change, improving its quality. Marshall, Santos and Carvalho have shown the possibilities that civil, political and social rights can provide through the access to education, health, housing and employment amongst other, convenient to those who are excluded from the social process.

The lack of rights is constituted of a vicious cycle that makes bigger the distance between rich and poor, the ones who are in the center and those from the outskirts, a few ones able and other much unable to cyberspace, some employed and others unemployed. After all, one spends more to live in the outskirts of a city to have less conditions and services than in the great centers of power. Cities have been transformed into unique and complex systems that 
represent the social classes' conflict as the reflex of social contract, which prizes for economic development to the detriment of the citizens' rights - we have become consumers. The consumer's market space is developed while the citizen space shrinks before the space dialectics. Social conflicts that make themselves present and are of much importance to citizenship construction.

Digital inclusion can promote individuals participation in cyberspace, which becomes every day the public debates sphere and that presents itself as the space for State decisions. Additionally, what is going to make individuals seek social information in such space will be the necessity of belonging somewhere, a work space - even before the existence of critical awareness of cyberspace.

Regulated citizenship, according to Santos (1979) is still present in Brazilian society nowadays, demanding from individuals a formal occupation to ensure their citizen's rights citizenship. And regulation is based on technique and technology, used by the hegemonic sectors of society downwards, creating favorable conditions for their economic development, but unfavorable ones to those who are in the bottom part of social system - the poor.

For workers - especially the dispossessed residents of the metropolis outskirts of a country with a super high index of social inequality as in Brazil -, technique in its current stage is not only a foreign but something that arrives downwards, because as a rule, only hegemonic social actors combine the necessary conditions for the production of new technologies; which does not constitute any news considering that since the late $19^{\text {th }}$ century, "industrial investigation of great style, science, technique and the capital revaluation converge in only a sytem" (Habermas, 1968, p.72), that is, given the appropriation of science and technology by capitalism and their setting for its service. (Becker, 2009, p. 69)

However, dialectics of space makes possible the conflicts between social inequality reduction and the widening of the gap between rich and poor. And by thinking of citizenship as equality, we see digital inclusion as a possible way to access information and services that can reduce social inequality. Such critical knowledge can unleash a process of critical view construction of the other vehicles of communication and information, as television, radio and others, because the manner how culture is displayed and created in society makes it a place of conflict and debate.

However, the access to information technology and communication doesn't necessarily mean that everyone takes equal advantage of information available because it depends on the individual who is accessing the available information as a critical being. Every human being has the right of freedom of opinion and expression; such right includes the liberty of having opinions and searching, receiving and transmitting information and ideas without interference by any means and independently of boundaries. It is, therefore, an 'expanded' right whose concept suggests not only giving the voice to the unvoiced, but every condition necessary for communication to happen. These conditions are both made possible and, at the same time, subtracted by technologic development because of the monopolist concentration of technological property "blocks the possibility of common people making themselves be 
heard," i. e., "subordination to the market's rules to which there are only consumers, not citizens, has meant the communication divestment of its social and public asset aspect, converting it on a simple commodity" (ALAI, 2001) (Becker, 2009, p. 126).

The right of standing and fighting for rights is a fundamental part in citizenship construction, allowing citizens to make themselves be heard and this way taking part in political decisions. "It can be said that, greater is the involvement of a person in citizenship action, or socialpolitical-cultural engagement of the citizen, greater is the emphasis on the expression of the change feeling" (Becker, 2009, p. 162). Thus, the individuals have the right of social belonging, in which they can see themselves as citizens engaged in social-political-cultural changes in society, building a space of socialization and full citizenship.

\section{Employability and digital inclusion: Inclusion based upon social occupation}

The critical use of information techniques and technology along with other actions for the promotion of equality, can lead citizens to their full citizenship development, which demands a new transformation on work directions, which today is responsible for occupation and social insertion.

For Antunes (2001), work category has it centrality "in contemporary formation of society" (p. 13), where new manners of production are capable of transforming work organization and consequently, social occupation. Social occupation, because of its history and totality, is what provides forces to individuals that strengthened in social space, be able to promote some transformation in its life and present results contrary to what social exclusion reserve. Nevertheless, the promotion of those spaces within informational capitalism first demands that marginalized individuals gain forces to promote the conflict, reclaiming their right to full citizenship. After all, the same place alienates, can be the one that promotes transformation.

Antunes (1999) also ponders that the capitalist production system has been experiencing great transformation, "either on its materiality ways, as in the subjectivity sphere, given the complex relations between the ways of being and existing of human sociability" (p. 15). And that such transformation would lead to the increase of structural unemployment and precarious conditions of the workers among others related to "the production of goods" and "the valorization of capital".

The informational and cultural content produced based on immaterial product does not dissipate with consume, on the contrary, it gets wider and is spread by communication channels for the consumption of other people, increasing its diffusion. However, there is the estrangement by the workers when it comes to immaterial work that does not suit their intellectual work development. This way, the alienation of the worker that "means the existence of the capital" is also the fight "of the being against suffering", according to Antunes (1999, p. 132). Antunes (1999) defends that there is no material work that can replace immaterial work, but a greater relation between them and their techniques and new technologies, which demands from the worker abilities and competences. 
Work, as the generator of social values, corresponds to social occupation, where citizens belong to the social environment and, this way, once they are inserted in it, they can transform the same environment that transform them. Thus, researches are conducted with the intent of demonstrating how important employment and social insertion are, and to accomplish it, the unemployed need to enable them by seeking their insertion in social programs that offer vocational training. And when the unemployed resides in the poor periphery of great metropolis, they usually look for free courses.

Van Acker and Rabia (2009) defend that the unemployed that take part in social programs of digital inclusion have to be inserted by "the labor market that must not only consider the employment acquisition, but ensure they make this same labor market reading and use their resources and information accordingly to their purposes, personal projects and sense of social belonging" (p. 31). The search for a job have led individuals to seek social programs of digital inclusion that focus on computer skills and employment, in the attempt to correspond the demands of the labor market, transformed by the informational capital. The main problem that demands the adequacy of such programs is that providing access to technology does not constitute the social insertion of the users or their informational literacy, as proposed by Massensini (2010).

Van Acker and Rabia (2009) point out that "the ability and access to technology do not guarantee employability" (p. 71) that demands a variety of factors associated in almost perfect harmony, such as family structure and economic conditions. "It is hereby reinforced the observation that the access to important data for the insertion in the labor market did not depend only on the access to computers. It depended much more on the acquisition of a previous repertoire, which would allow the search of desired information" (Van Acker \& Rabia, 2009, p. 74).

For Van Acker and Rabia (2009), digital inclusion that limited its concept "to the access and domain of basic software operations" (p. 87) distances itself from the ideal discussed by the researcher cited above. And yet, in a perverse way, practices only the consumption of new technologies. Digital inclusion for employability goes beyond the social programs of digital inclusion have been promoting, once the users are able to transform themselves in full citizens, with civil, political and social rights, and not only consumers of products.

Nonetheless, family income along with other social problems leads unemployed to subaltern jobs; once they seek professional alternatives to respond more quickly to their basic needs. In this manner, what is perceived is that social programs of digital inclusion, practiced as inclusion space for equipment do not solve the poverty problems, though they somewhat contribute.

Van Acker and Rabia (2009) point out on their studies, that "no vehicle of information approaches the matter of structural unemployment, social differences and possibilities (or the lack of them) of social mobility" (p. 135), making the unemployed to blame themselves for their conditions, instead of analyzing in a critical way the economic situation they have been exposed to during their lives. And yet, that many of them seek only to respond their basic needs and not their desires and dreams. 
On the other hand, social programs of digital inclusion enable "the education, information and formation of social networks that are so rich, contributing to the life improvement of its users" (Van Acker \& Rabia, 2009, p. 149) discuss. In as much as, the necessary adequacies are considered, those programs can go "further than simple access" to computers and internet, providing changes and conquests in social space.

\section{Conclusion}

Citizenship professes education as being the primary right to education, according to Marshall (1967), Carvalho (2003) and Santos (2008), and, therefore, the discussion on the practice of literacy related to digital inclusion is convenient for the visualization of its social transformation potentiality. The model of informational literacy is the one on which individuals are literate, and deal with information through information and communication technologies, in a critical way and with conscious awareness of their own learning process.

It is necessary to promote informational literacy that can provide the individuals' informational capacity, so that they contribute to the construction of full citizenship and make themselves citizens. Education is a right sine qua non the conquest of the civil, political and social rights capable of socially including individuals, promoting the necessary conditions for them to fight on equal footing for a more just and less poor society. For that purpose, using the approximately 5,700 telecenters as a support point for the education of Brazilian citizen and, therefore, promoting the rights and the construction of citizenship can be a possible way for historic-social transformation and inclusion.

\section{References}

Antunes, R. (2001). Os sentidos do trabalho: ensaio sobre a afirmação e a negação do trabalho. $\left(4^{\text {th }}\right.$ ed.) São Paulo: Boitempo Editorial.

Becker, M. L. (2009). Inclusão digital e cidadania; as possibilidades e as ilusões da solução tecnológica. Ponta Grossa: UEPG. 
Carvalho, J. M. (2003). Cidadania no Brasil: o longo caminho. 4 ed. Rio de Janeiro: Civilização Brasileira.

Costa, S. (2002). As cores de Ercília: esfera pública, democracia, configurações pósnacionais. Belo Horizonte: Editora UFMG.

Demo, P. (1995). Cidadania tutelada e cidadania assistida. São Paulo: Autores Associados.

Marshall, T. H. (1967). Cidadania, classe social e status. (trad. Meton Porto Gadelha). Rio de Janeiro: Zahar Editores.

Massensini, R. L. (2010). Inclusão digital no Centro Vocacional Tecnológico Henfil: uma leitura sob a ótica do capitalismo informacional. Dissertação apresentada ao Programa de Pós-Graduação da Escola de Ciência da Informação. Minas Gerais: UFMG.

Oliveira, Francisco de, PAOLI, Maria Célia (Org.). (1999). Os sentidos da democracia; políticas do dissenso e hegemonia global. Rio de Janeio: Vozes; Brasília: NEDIC.

Onid (Observatório Nacional de Inclusão Digital). (2010). Mapa de telecentros. Ministério do Planejamento, Orçamento e Gestão.

Santos, M. (2007). O espaço do cidadão.( 7thed.) São Paulo: EDUSP.

Santos, M. (2008). A natureza do Espaço: técnica e tempo, razão e emoção. 4ed. São Paulo: EDUSP.

Santos, Wanderley Guilherme dos. (1979). Cidadania e justiça: a política social na ordem brasileira. Rio de Janeiro: Campus.

Van Acker, Maria Teresa Vianna, RABIA, Selim, PASSARELI, Brasilina. (2009). Inclusão digital e empregabilidade. São Paulo: Senac. 